\title{
The Effect of Differentiated Science Curriculum on Students' Motivational Regulations ${ }^{\mathrm{i}}$
}

\author{
Neşe Kutlu Abu*, Murat Gökdere \\ Faculty of Education, Amasya University, Turkey
}

Copyright $\bigcirc 2018$ by authors, all rights reserved. Authors agree that this article remains permanently open access under the terms of the Creative Commons Attribution License 4.0 International License

\begin{abstract}
The purpose of this study is to examine whether the Grid Model practices affect students' motivation for self-regulation. In the study, quasi-experimental research design with pre-test/post-test control group was used. This study was conducted with a total of 74 students from $4^{\text {th }}$ grade students in different primary schools in Amasya. Motivated Strategies for Learning Questionnaire was used as data collection tool. The obtained data was analyzed in the SPSS program and parametric tests were used in the analysis of the data. According to the findings obtained, there was a significant difference in favor of the experimental group among the students' post-test scores of internal goal orientations, task values and self-efficacy perceptions at public schools. As a result of the research, the Grid Model has provided that the students with low socio-economic level have increased their motivation towards self-regulation and the students with high socio-economic level have continued their high motivation levels. In the future studies, it can be seen whether the Grid Model-based applications have an effect on the behavioral, contextual and cognitive regulation dimensions of the students.
\end{abstract}

Keywords The Grid Model, Primary School Students, Motivation for Self-regulation

\section{Introduction}

In the educational curriculum, individuals show considerable differences in their learning outcomes and in the way they reflect learning experiences into real life, despite the fact that they live in the same educational and training process. Interests, learning preferences, abilities, intelligence, psychological and sociodemographic characteristics of students differ from each other. Naturally, this can affect the learning process and academic achievements in a positive or negative way. In a study conducted by Jonassen and Grabowski [1], it was suggested that individual differences may affect students' learning attitudes and their way of applying certain implications for new situations. From this point of view, it is important to consider individual differences in ensuring individual development and integration with the society.

In order to provide qualified education, it is necessary to reorganize the education and training activities by considering the individual differences of the students $[2,3$, 4]. When the related literature is examined, it has been shown that the students who are educated based on individual differences develop the course success in a positive way and this situation increases the permanent learning $[5,6,7]$. Disadvantaged students may be neglected or individual development of all students may not be achieved in educational settings where individual differences are not taken into account [8], Renzulli [9], noted that in schools where traditional teaching methods are used or disadvantaged students are enrolled, enrichment programs can be used to meet the educational needs of students. In enriched learning environments, students are directed to a variety of studies, taking into account the interests of students and their learning preferences [10]. In enrichment programs, students can work in depth and field trips in their area of interest. They can be engaged in real life problems and can cooperatively join ability groups $[11,12]$.

Many differentiated curriculum models have been developed and implemented as enrichment programs from the past to the present day. As examples of some of these models; Schoolwide enrichment model, Purdue model, Integrated curriculum model, Maker model, Grid model, Autonomous learning model model can be given. The Grid model is the most notable one among the differentiated models of education based on the rearrangement of the existing curriculum to the principles of depth and complexity without changing the scope of the general education curriculum. The Grid model applications are implemented in Gifted and Talented Education (GATE) programs [13, 14]. This model provides interdisciplinary learning opportunities for 
students [15]. In the model, learning objectives, content, process and learning products are organized by structuring according to themes [16]. According to the principles of depth and complexity, eleven indicators were defined in the grid model as; discipline's language, details, patterns, trends, unanswered questions, rules, ethics, great ideas, timing, perspective, and interdisciplinary [15]. The key features of this curriculum differentiated for gifted students are [16]:

\begin{abstract}
"Curriculum content is associated with current, broad-based issues, with themes and problems. As content is integrated into different disciplines in the workplace, the opportunity to experience various aspects of the workplace is presented. The core skills of the curriculum are integrated with high-level thinking skills, and high-level thinking skills are developed by focusing on open-ended tasks. They are encouraged to develop products for existing ideas and are encouraged to produce new ideas. Product development is supported using techniques, materials, and forms and steps are taken to ensure the learners' own development. "
\end{abstract}

When the relevant literature is examined, the practices on basis the Grid model suggest that they contribute for gifted or non-gifted learners to establish interdisciplinary relationships, and that they find this model interesting, useful or challenging [15]. In a study conducted by Manzone [13], it was found out that students were successful in transferring the elements in the curriculum in Grid model-based activity tasks. Grubb [14] reported that this model improved both the teachers' and students' intellectuality in a positive way. In a study by Hunt and Yoshida [17], it was argued that this model was used with the Link project and that the model contributed to the identification of the gifted students. In the evaluation of the programs in which the model is applied, it is also observed that a measurement tool called DC-PET is given the relevant literature [18].

In a study by Park [19], it was noted that it is not difficult for teachers to understand the differentiation with the Grid model, but it was argued that there are difficulties in transferring the information about the model to classroom implementations. In this study, it was reported that teachers should be trained with demonstration courses to support the practice of depth and complexity directors. In the studies conducted, it seems that the Grid model has generally positive effects on gifted or non-gifted students and professional development. However, no studies that were conducted on whether this model influences self-regulatory skills, among the lifelong learning ones, of all gifted, or non-gifted learners have been encountered.
The Grid model is thought to be useful in the development of self-regulation of students. In the Grid model applications, the content and learning environment are organized according to the interests of the students and their learning preferences, and the learning process is enriched based on the individual differences. Under the model, students can identify their own learning deficiencies, re-plan their learning, and evaluate their own learning outcomes. Students may have the opportunity to develop self-learning skills in Grid-based learning environments. Therefore, in this present study, it will be tried to experimentally test whether the Grid model-based applications have an effect on students' self-regulatory skills. This study is seen important in terms of revealing the general methods and models that develop self-regulatory learning skills or that do not affect the development of these skills. This study is also important in terms of presenting the opportunity to experience activities enriched by students with different intelligence and learning levels and to gain the relevant literature on the differentiated curriculum developed within the scope of the study. This study is also regarded as important in terms of presenting the opportunity to experience activities enriched with students of different intelligence and learning levels and contributing to relevant literature by presenting the differentiated curriculum developed.

The purpose of this study is to examine the effect of science activities based on the Grid model on the motivation of students to self-regulation. In this respect, the question of "how is the effect of science activities based on the Grid model on students' self-regulation situations (internal goal orientation, external goal orientation, task value, learning control belief, self-efficacy perception and test anxiety dimension)?. The sub-problems of the study are;

1. Is there a significant difference between the averages of "internal goal orientations, external goal orientation and task value, learning control belief, self-efficacy and test anxiety scores" and pre-test score averages of experimental groups and control groups?

2. Is there a significant difference between the "internal and external goal orientations and task value, learning control belief, self-efficacy perception, test anxiety" post-test scores of experimental groups and control groups?

3. Is there a significant difference between the "internal and external goal orientations and task value, learning control belief, self-efficacy perception, test anxiety" pre-test scores and post-test scores of experimental group I and II ? 


\section{Materials and Methods}

\subsection{Research Design}

Semi-experimental design with pre-test-post-test control group which is one of the quantitative research methods was used. In the design, experimental and control groups were randomly selected from previously formed groups [20]. At the time of selection of the experimental and control groups, the 4th grade students with at least one gifted in their class was determined as criteria. At the provincial center, the number of public and private schools with these characteristics was determined, and two branches (one private, one public school) and two controls (one private, one public school) groups were randomly selected from the branches in these schools. The reason for the choice of two experiments and two control groups is to increase the number of subjects and to evaluate the implementation of the model in schools at different socio-economic levels. The participant students were prevented from interacting with each other thanks to the selection the experimental and control groups in different schools. Before the experimental procedure was started, the Motivated Strategies for Learning Questionnaire (MSLQ) scale was applied as a pre-test to the experimental and control groups and the final test data were collected after the experimental procedure. Independent variables of experimental applications are science curriculum based on Grid model, while dependent variables are motivation of students for self-regulation. The experimental design of the study is given in Table 1.

Table 1. The experimental design of the study

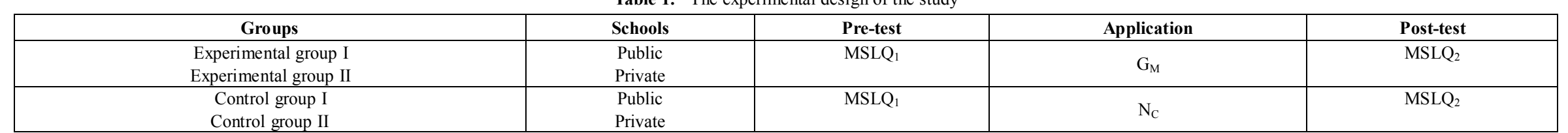

MSLQ: Motivated Strategies for Learning Questionnaire; $\mathrm{G}_{\mathrm{M}}$ : Grid curriculum-based training; $\mathrm{N}_{\mathrm{C}}$ : General Science Curriculum

\section{2. Study Group}

This study was carried out with a total of 74 participants consisting of 4th grade students in 4 different schools, including 2 private schools in Amasya and 2 other public schools affiliated to MoNE (Ministry of National Education). In order to define the study group, having at least one gifted student recognized by the Guidance and Research Center was used as criteria. The information of the study group is given Table 2.

Table 2. The information of the study group

\begin{tabular}{|c|c|c|c|c|c|c|c|c|c|c|c|c|}
\hline \multirow[b]{2}{*}{ Groups } & \multirow[b]{2}{*}{ Students } & \multirow[b]{2}{*}{$\mathrm{N}$} & \multicolumn{2}{|c|}{ Gender } & \multicolumn{2}{|c|}{ School } & \multicolumn{3}{|c|}{ Mother education status } & \multicolumn{3}{|c|}{ Father education status } \\
\hline & & & Female & Male & Private & Public & $\begin{array}{c}\text { Primary/ } \\
\text { Elementary }\end{array}$ & High school & $\begin{array}{l}\text { License/ up } \\
\text { graduate }\end{array}$ & $\begin{array}{c}\text { Primary/ } \\
\text { Elementary }\end{array}$ & High school & $\begin{array}{l}\text { License/ up } \\
\text { graduate }\end{array}$ \\
\hline \multirow{2}{*}{ Experimental group I } & Gifted & 1 & 1 & - & - & 1 & - & - & 1 & - & - & 1 \\
\hline & Non gifted & 19 & 7 & 12 & - & 19 & 10 & 4 & 5 & 7 & 3 & 9 \\
\hline \multirow{2}{*}{ Experimental group II } & Gifted & 2 & 1 & 1 & 2 & - & - & - & 2 & - & - & 2 \\
\hline & Non gifted & 16 & 10 & 6 & 16 & - & 0 & 2 & 14 & 1 & 3 & 12 \\
\hline \multirow{2}{*}{ Control group I } & Gifted & 1 & - & 1 & - & 1 & - & - & 1 & - & - & 1 \\
\hline & Non gifted & 20 & 9 & 11 & - & 20 & 4 & 4 & 12 & 2 & 2 & 16 \\
\hline \multirow{2}{*}{ Control group II } & Gifted & 1 & - & 1 & 1 & - & - & - & 1 & - & - & 1 \\
\hline & Non gifted & 19 & 13 & 6 & 19 & - & 0 & 8 & 11 & 0 & 6 & 13 \\
\hline
\end{tabular}




\subsection{Data Gathering Tool}

Motivated Strategies for Learning Questionnaire (MSLQ) developed by Pintrich and De Groot [21] and adapted to Turkish by Karadeniz et al. [22] was used as data collection tool. Developed by Pintrich and De Groot [21] the reason for using this scale is that it is a measurement tool that provides multidimensional information about the motivational, behavioral, cognitive, and contextual sub-structures of the self-regulation rather than the superficial evaluation of students' self-regulation skills. The validity and reliability study of this scale, adapted by Karadeniz et al. [22], was conducted for students in the 12-18 age groups. Only the motivational dimension of the MSLQ scale was analyzed. The motivational part of the MSLQ scale consists of a total of six sub-dimensions: internal goal orientation, external goal orientation, control belief, task value, self-efficacy, and test anxiety. Since the students in the study group were in the 10-11 age group, the Cronbach Alpha reliability scores of pre-test and post-test motivation scores of the scale adapted by Karadeniz et al. [22] were recalculated and our reliability values were found high.

\subsection{Designing Activities}

The learning outcomes of the Light and Sound unit for the 4th grade of the Science course were examined and the existing learning outcomes were classified according to Bloom taxonomy [23]. The related literature about the Grid model has been examined and it has been tried to determine which theme and disciplines will be related in the Light and Sound units. Using the Total Talent Portfolio developed by Renzulli and Purcell [24], necessary information about gifted students was collected. The framework of the differentiation to be made in the learning process has been determined according to the information obtained.

The information elements that make up the content of the Light and Sound Units are classified according to concept, principle and generalization. By linking the changing theme with the information groups in the context, differentiated learning outcomes were created according to the upper echelons of the Bloom taxonomy. To develop students' in-depth thinking skills; in the learning outcomes, the causality and the relations between events or situations are pre-regulated.

Activities were presented to the students in a way that they were integrated into different disciplines such as archeology, astronomy, chemistry and design. In the activities, the scope of lighting devices and light technologies has been expanded by means of current topics including different light technologies such as radio telescopes, optical telescopes and mirrored telescopes. Opportunities have been provided for different experiences where students will be active and able to provide individual development with the developed activities. Predictive-observation-research activities have been carried out to develop students' different thinking skills. Students were offered the opportunity to choose one or several of the activities developed for them to learn in depth with self-directed topics independently. Posters were prepared for students to use at the corner of interest in classroom, and activities were organized to develop students' research skills. For pupils, various forms have been developed and implemented for designing at the point of problem solving and research.

\subsection{Implementations}

Prior to the start of the implementations, the experimental group teachers were trained on the Grid model and activity implementations. Pilot schemes were conducted before the implementations and some problems related to them were identified. A new education was given to the teachers and these problems were tried to be solved. Before the actual implementations, the MSLQ scale was applied to four groups consisting of two experimental groups and two control groups, and related data were collected.

The actual practice lasted for 7 weeks, with a total of 42 teaching hours for the students in the two experimental groups. MoNE's specified time period for Light and Sound Units has not been exceeded. In the experimental group I and II, the course was taught with activities based on the Grid model, and the existing science curriculum in control groups I and II was performed. After the implementation, the MSLQ scale was reapplied to all groups and data were collected.

Tablo 3. The information about the experimental process

\begin{tabular}{|cccccc|}
\hline & N & $\begin{array}{c}\text { The areas where the activities were } \\
\text { performed }\end{array}$ & Duration & $\begin{array}{c}\text { Class } \\
\text { Hours }\end{array}$ \\
\hline \multirow{2}{*}{$\begin{array}{c}\text { Experimental } \\
\text { group I }\end{array}$} & $\begin{array}{c}\text { Activities done by the } \\
\text { whole class }\end{array}$ & 20 & Normal classroom & 7 weeks & 21 \\
\cline { 2 - 6 } & Resource room activities & $1^{*}$ & $\begin{array}{c}\text { Support classroom in the school, } \\
\text { university laboratory }\end{array}$ & 5 weeks & 8 \\
\hline $\begin{array}{c}\text { Experimental } \\
\text { group II }\end{array}$ & $\begin{array}{c}\text { Activities done by the } \\
\text { whole class }\end{array}$ & 18 & Normal classroom & 7 weeks & 21 \\
\cline { 2 - 7 } & Resource room activities & $2^{*}$ & $\begin{array}{c}\text { Support classroom in the school, } \\
\text { university laboratory }\end{array}$ & 5 weeks & 8 \\
\hline
\end{tabular}

*Gifted student(s) 


\subsection{Analysis of Data}

The Kolmogorov-Smirnow test was conducted to examine the normal distribution of data pertaining to pre-implementation motivation dimension of the students in the study group. The results of the Kolmogorov-Smirnow normality test are given in Table 4.

Table 4. Distribution of data in the motivation dimension of the students in the study group

\begin{tabular}{|c|c|c|}
\hline \multirow{2}{*}{} & \multicolumn{2}{|c|}{ Kolmogorov-Smirnov } \\
\cline { 2 - 3 } & Statistic & p \\
\hline Experimental group I &, 195 &, 054 \\
\hline Control group I &, 154 &, 200 \\
\hline Experimental group II &, 197 &, 098 \\
\hline Control group II &, 164 &, 191 \\
\hline
\end{tabular}

When Table 4 is examined, the significance levels of the Kolmogorov-Smirnov test of experimental and control groups are larger than 0.05 . The motivational scores show normal distribution because the significance value of the obtained data is greater than 0.05 [25]. Therefore, in the analysis of these data, it is accepted that the data are distributed normally and parametric tests are decided to be used.

\section{Findings}

\subsection{Findings Related to the First Sub-problem}

The first sub-problem of the study is "Is there a significant difference between the averages of internal goal orientations, external goal orientation, task value, learning control belief, self-efficacy and test anxiety scores" pre-test score averages of experimental groups and control groups?" To find a response to this sub-problem, and ANOVA from parametric tests was performed. ANOVA results on the pre-test scores of the motivation sub-dimensions of the students in the experimental and control groups are given in Table 5 .

Table 5. The results of the ANOVA test for the pre- test score averages of motivation sub-dimensions of students in experimental and control groups

\begin{tabular}{|c|c|c|c|c|c|c|}
\hline & & Sum of Squares & df & Mean Square & $\mathbf{F}$ & $\mathbf{P}$ \\
\hline \multirow{3}{*}{ Internal goal orientation } & Between Groups & 4,119 & 3 & 1,373 & ,892 &, 450 \\
\hline & Within Groups & 107,791 & 70 & 1,540 & & \\
\hline & Total & 111,910 & 73 & & & \\
\hline \multirow{3}{*}{ External goal orientation } & Between Groups & 9,894 & 3 & 3,298 & 2,240 & ,091 \\
\hline & Within Groups & 103,044 & 70 & 1,472 & & \\
\hline & Total & 112,938 & 73 & & & \\
\hline \multirow{3}{*}{ Task value perception } & Between Groups & 3,431 & 3 & 1,144 & 1,212 & ,312 \\
\hline & Within Groups & 66,033 & 70 & ,943 & & \\
\hline & Total & 69,464 & 73 & & & \\
\hline \multirow{3}{*}{ Learning control perception } & Between Groups & 2,786 & 3 & ,929 &, 818 & ,488 \\
\hline & Within Groups & 79,486 & 70 & 1,136 & & \\
\hline & Total & 82,272 & 73 & & & \\
\hline \multirow{3}{*}{ Self-efficacy } & Between Groups & 5,057 & 3 & 1,686 & 1,228 & ,306 \\
\hline & Within Groups & 96,055 & 70 & 1,372 & & \\
\hline & Total & 101,111 & 73 & & & \\
\hline \multirow{3}{*}{ Exam anxiety } & Between Groups & 10,530 & 3 & 3,510 & 3,466 &, $021 *$ \\
\hline & Within Groups & 70,889 & 70 & 1,013 & & \\
\hline & Total & 81,418 & 73 & & & \\
\hline
\end{tabular}

$* \mathrm{p}<0,05$

According to Table 5, there is a meaningful difference in the test anxiety dimension while there is no significant difference between experimental and control groups' internal and external target orientation, task value, learning control belief, pre-test averages regarding self-efficacy dimensions. When the posthoc test was performed to investigate the source of significant difference in the dimension of the test anxiety scale, it was found that the source of the difference was between the control group I and the control group II, between the experimental group II and the control group I. 


\subsection{Findings Related to the Second Sub-problem}

The second sub-problem of the study is "Is there a meaningful difference between the intrinsic and extrinsic goal orientations of the students in the experimental and control group, task value, learning control belief, self-efficacy perception, test anxiety post test scores?" ANOVA test was conducted to be able to find the answer to this research question. The ANOVA test results of the students in the experimental and control groups regarding the internal target orientation, task value, and self-efficacy final test point averages are shown in Table 6 .

Table 6. Results of the ANOVA test for the post-test score averages of the internal goal orientations, task values, and self-efficacy of students in experimental and control groups

\begin{tabular}{|c|c|c|c|c|c|c|c|}
\hline & & $\begin{array}{r}\text { Sum of } \\
\text { Squares }\end{array}$ & df & $\begin{array}{c}\text { Mean } \\
\text { Square }\end{array}$ & $\mathbf{F}$ & $\mathbf{p}$ & Posthoc test \\
\hline \multirow{3}{*}{ Internal goal orientation } & Between Groups & 28,712 & 3 & 9,571 & 7,485 &, $000^{*}$ & \multirow{3}{*}{$\begin{array}{l}\text { Experimental I- Control I, } \\
\text { Experimental II- Control I }\end{array}$} \\
\hline & Within Groups & 89,504 & 70 & 1,279 & & & \\
\hline & Total & 118,216 & 73 & & & & \\
\hline \multirow{3}{*}{ External goal orientation } & Between Groups & 9,894 & 3 & 3,298 & \multirow{3}{*}{2,240} & \multirow{3}{*}{,091 } & \\
\hline & Within Groups & 103,044 & 70 & 1,472 & & & \\
\hline & Total & 112,938 & 73 & & & & \\
\hline \multirow{3}{*}{ Task value } & Between Groups & 11,833 & 3 & 3,944 & 4,105 &, $010^{*}$ & \multirow{3}{*}{$\begin{array}{l}\text { Experimental I-Control I, } \\
\text { Control I-Control II }\end{array}$} \\
\hline & Within Groups & 67,267 & 70 & 961 & & & \\
\hline & Total & 79,101 & 73 & & & & \\
\hline \multirow{3}{*}{ Learning control } & Between Groups & 10,553 & 3 & 3,518 & 2,336 &, 081 & \\
\hline & Within Groups & 105,387 & 70 & 1,506 & & & \\
\hline & Total & 115,940 & 73 & & & & \\
\hline \multirow{3}{*}{ Self-efficacy } & Between Groups & 13,341 & 3 & 4,447 & 4,221 &, $008 *$ & \multirow{3}{*}{ Experimental I-Control I } \\
\hline & Within Groups & 73,753 & 70 & 1,054 & & & \\
\hline & Total & 87,095 & 73 & & & & \\
\hline \multirow{3}{*}{ Exam anxiety } & Between Groups & 5,906 & 3 & 1,969 & 1,044 & ,378 & \\
\hline & Within Groups & 131,949 & 70 & 1,885 & & & \\
\hline & Total & 137,855 & 73 & & & & \\
\hline
\end{tabular}

${ }^{*} \mathrm{p}<0,05$

When Table 6 is examined, there is a significant difference between the post-test mean scores of internal goal orientations, task values, and self-efficacy of the students in experimental and control groups. According to the results of the posthoc test applied to examine the source of the difference; there is a significant difference between experimental group I and control group I, and between experimental group II and control group II in terms of internal goal orientation post test scores. The mean of self-efficacy post-test scores differentiate between experimental group I and control group I; and the mean of task value post-test scores also differentiate between experimental group I and control group I and between control group I and control group II.

According to the Table 6, mean scores of students' learning control, external goal orientation and exam anxiety post-test scores do not differ significantly according to experimental and control groups.

\subsection{Findings Related to the Third Sub-problem}

The third sub-problem of the study is "Is there a meaningful difference between the internal and external target orientations of the students in the experimental groups, task value, learning control belief, self-efficacy perception, test anxiety pre-test and post-test scores?" Dependent sample t-test was performed to test this sub-problem. The results of the dependent sample t-test for comparing the pre-test and post-test scores of the motivational dimensions of the students in the experimental group I are shown in Table 7. 
Table 7. Dependent sample t-test for comparison of pre-test and post-test scores on motivation dimensions of students in experimental group I

\begin{tabular}{|c|c|c|c|c|c|c|}
\hline & Tests & Mean & Ss & $\mathbf{t}$ & Sd & $\mathbf{p}$ \\
\hline \multirow{2}{*}{ Internal goal orientation } & Pre-test & 5,29 & 1,33 & \multirow{2}{*}{$-2,988$} & \multirow{2}{*}{18} & \multirow{2}{*}{, $008^{*}$} \\
\hline & Post- test & 6,32 &, 87 & & & \\
\hline \multirow{2}{*}{ External goal orientation } & Pre-test & 5,70 & 1,14 & \multirow{2}{*}{,- 922} & \multirow{2}{*}{18} & \multirow{2}{*}{,369 } \\
\hline & Post- test & 6,07 & 1,08 & & & \\
\hline \multirow{2}{*}{ Goal value perception } & Pre-test & 6,13 & ,64 & \multirow{2}{*}{,- 742} & \multirow{2}{*}{18} & \multirow{2}{*}{,468 } \\
\hline & Post- test & 6,28 &, 76 & & & \\
\hline \multirow{2}{*}{ Learning control perception } & Pre-test & 5,50 &, 87 & \multirow{2}{*}{$-2,036$} & \multirow{2}{*}{18} & \multirow{2}{*}{, 057} \\
\hline & Post- test & 6,07 & 1,03 & & & \\
\hline \multirow{2}{*}{ Self-efficacy } & Pre-test & 5,59 & 1,01 & \multirow{2}{*}{$-2,327$} & \multirow{2}{*}{18} & \multirow{2}{*}{, $032 *$} \\
\hline & Post- test & 6,37 & ,95 & & & \\
\hline \multirow{2}{*}{ Exam anxiety } & Pre-test & 3,90 & ,92 & \multirow{2}{*}{$-1,105$} & \multirow{2}{*}{18} & \multirow{2}{*}{,284 } \\
\hline & Post- test & 4,29 & 1,56 & & & \\
\hline
\end{tabular}

$* \mathrm{p}<0,05$

When Table 7 is examined, there is a meaningful difference between the intrinsic goal orientation and self-efficacy scores and the pre-test scores in the experimental group I, whereas there is no significant difference between the external target orientation, learning control beliefs and test anxiety dimensions. The dependent sample t-test for comparing the pre-test and post-test scores of the motivational dimensions of the students in Experimental Group II are shown in Table 8.

Table 8. Dependent sample t-test for comparison of pre-test and post-test scores on motivation dimensions of students in experimental group II

\begin{tabular}{|c|c|c|c|c|c|c|}
\hline & Tests & Mean & Ss & $\mathbf{t}$ & sd & $\mathbf{p}$ \\
\hline \multirow[t]{2}{*}{ Internal goal orientation } & Pre-test & 5,6563 & 1,11009 & \multirow{2}{*}{$-1,765$} & \multirow{2}{*}{15} & \multirow{2}{*}{,098 } \\
\hline & Post- test & 6,1563 & ,52341 & & & \\
\hline \multirow[t]{2}{*}{ External goal orientation } & Pre-test & 5,5625 & 1,23360 & \multirow{2}{*}{$-1,366$} & \multirow[t]{2}{*}{15} & \multirow{2}{*}{, 192} \\
\hline & Post- test & 6,0000 & 1,02560 & & & \\
\hline \multirow{2}{*}{ Goal value perception } & Pre-test & 6,0625 & 1,01382 & \multirow{2}{*}{,- 446} & \multirow{2}{*}{15} & \multirow[t]{2}{*}{,662 } \\
\hline & Post- test & 6,2250 &, 89703 & & & \\
\hline \multirow{2}{*}{ Learning control perception } & Pre-test & 5,8542 & ,99606 & \multirow[t]{2}{*}{, 876} & \multirow[t]{2}{*}{15} & \multirow{2}{*}{,395 } \\
\hline & Post- test & 5,5833 & ,89856 & & & \\
\hline \multirow{2}{*}{ Self-efficacy } & Pre-test & 6,0500 & 1,11595 & \multirow{2}{*}{, 347} & \multirow{2}{*}{15} & \multirow{2}{*}{, 733} \\
\hline & Post- test & 5,9125 & ,99591 & & & \\
\hline \multirow{2}{*}{ Exam anxiety } & Pre-test & 4,6875 & ,79320 & \multirow{2}{*}{2,663} & \multirow{2}{*}{15} & \multirow{2}{*}{, $018^{*}$} \\
\hline & Post- test & 3,7500 & 1,65005 & & & \\
\hline
\end{tabular}

$*_{\mathrm{p}}<0,05$

When Table 8 is examined, the test anxiety sub-dimension of the motivation sub-dimension in the experimental group II is found to be a significant difference between the pre-test and post-test average scores, whereas the motive dimension is not significant in the other sub-dimensions.

\section{Discussion}

In the scope of the research, a differentiated curriculum with Grid model was designed for the Light and Sound Unit of $4^{\text {th }}$ grades. Whether the Grid model effected the students' motivations on their self-regulations were investigated by applying experimental research method. When findings related to the first sub-problem of the study were examined, it was seen that there was not a significant difference between the pre-test average scores of the other motivation dimensions of the experimental and control groups except for the test anxiety dimension (Table 5). From these findings, it can be said that the experimental and control groups have similar internal and external target orientation, task value, self-efficacy and learning control pre-test scores before the experimental process. This situation is desirable in terms of testability of the experimental process.

When findings related to the second sub-question of the study were examined, it was found that there was a 
significant difference between the experimental and control groups in internal motivation, task value and self-efficacy final test scores; external motivation, learning control, test anxiety post-test scores (Table 6). According to the results of the posthoc test to determine the source of the difference, it is seen that there is a significant difference between the internal goal orientation post-test test scores of the students in experimental groups I-II and control groups I-II, a significant difference in favour of the experimental group I and experimental group II can be seen. It can be said by way of these obtained findings, that the Grid model applied to private schools and public schools has positively influenced students in terms of internal goal orientations which are of the self-regulation dimensions. In other words, the Grid model enhances the students' internal goal orientations, i.e., students' positive responses to the tasks they perform when compared to the normal curriculum in science courses. The reason for this finding may be that problem-solving activities related to real life are included in the curriculum differentiated according to the Grid model and these activities are more meaningful to the students. Akdeniz [26] claimed that many science subjects are more understandable with the problem-solving approach and that this approach contributes to the understanding of the nature of the subject that the students are seeking. From the findings obtained from the research, it can be said that the motivation of the students towards self-regulation is increased by using the problem solving approach in the Grid model.

According to the posthoc results, a significant difference was found between the task value post-test test scores of the experimental group I and the control group I (Table 6). When these score averages are analyzed, it is seen that the score average of the public schools affiliated to MoNE is higher than that of the control group. The task value represents an ordinary attitude such as enjoying a given task about a subject. According to the findings, it can be said that the general attitudes towards the science activities based on Grid model are positive. There are some other researches findings similar results to that of this study [15, 32]. Dodds [15] obtained some evidences proving the fact that the students considered the processes of this model as beneficial whether they are gifted or not. In a study by Çalıkoglu [32], it was found that the attitudes of gifted students towards science based on the features such as deepness and complexity were developed in a positive direction. The reason of this finding may have been doing enjoyable experiments based on the Grid model curriculum, preferable tasks, making designs via drawings, giving the opportunity to focus on different disciplines and interesting situations. From this point, the interests of the students to the science or other fields can be discovered through Grid model, enabling the students to study interdisciplinary areas. It is thought that the suitable opportunities can be provided the students for developing their skills by making it possible for them to study interdisciplinary areas with the aid of Grid Model.

According to posthoc results, when the self-efficacy post-test scores of control group I and control group I are compared, there is a significant difference in favor of experimental group I. That is, it can be said that Grid model applications in the public schools have a positive effect on the self-efficacy perceptions of the students than normal education curriculum. According to Bandura, self-efficacy means the beliefs of the students to their own skills in order to overcome the difficulties to reach the determined goals. The reason of the increasing the self-efficacy perception levels of the students in the other public schools affiliated to MoNE may have been the beliefs to their own skills as a result of being able to choose the activities appealing to their interests and accomplish them through Grid Model. The students may not be able to choose the activities appealing to their interests in the current curriculum. In a curriculum based on Grid model, the interests of the learners, their learning needs and preferences have been determined and interdisciplinary connections have been formed. In the model, the student-centered activities based on the individual preferences exist predominantly. Students are able to do tasks either individually or in groups in activities relied on this curriculum. Thanks to these kind of activities, it is thought that the students have a higher self-confidence, whereby developing their self-efficacies.

The individuals displaying a higher self-efficacy perception and self-regulation skill observe their own efforts during their tasks and compare their accomplishments with their goals and become more successful making self-evaluations about their accessibility to the goals [29]. The students' self-efficacy perceptions have increased and have become more self-regulation individuals with the help of Grid model activities. In a study by Mulyadi et al. [30], it was argued that the self-efficacy has a profound impact on self-regulation learning and that those with higher self-efficacy perceptions are less dependent teacher-centered approaches and methods in learning and can develop better self-learning strategies. The students can be more independent and autonomous in activities such as planning their own project and experiments and collecting data in student-centered classrooms [31]. The fact that the utilization of Grid model develops the students self-efficacies in a positive way are put forth by means of this study, as well.

According to the analysis done to determine how the Grid model affected the external goal orientations of the students, there isn't a significant difference between the post-test test scores of experimental group I-II and control group I-II (Table 5). External goal orientation can be defined as the conditions in which the students attribute the reason of doing a task to external factors such as getting high marks, winning awards or displaying better 
performance than others [21]. When this circumstance is taken into consideration, the reason of the students not developing external goal orientations may have arisen from that awards or graded marks aren't used in Grid model activities. In a study conducted by Yamaç [28], it was stated that some of the self-regulation learners develop self-regulation based on external factors such as awards or graded marks and that the internal goal orientation based on some factors such as curiosity and interest is more important in maintaining the self-regulation skills.

According to Ryan and Deci [27], even though the individuals seem inclined to their internal motivations, those tendencies just show up under certain conditions and these conditions form in the environments where the individuals express themselves naturally. It can be said that the current curriculum cannot proceed in the intended direction of creating the suitable environments mentioned above and developing the students' internal goal orientations in a positive direction, whereas Grid model is more successful than the normal curriculum. The students may perceive the activities conducted during the lesson as simple or purposeless when the necessary opportunities towards the developing their problem solving skills aren't/cannot be provided. In this situation, it wouldn't be logical to expect their internal goal orientations to develop in a positive way.

According to findings obtained for the third sub-problem, no significant difference was found between the internal and external target orientation, task value, self-efficacy perceptions, and learning control scores in pre-test and post-test results of experimental group II (Table 8). Those students are the ones who are educated in private schools. According to these findings, the students attending to private schools have generally higher levels of motivation pre-scores in self-regulation. The students attending to private schools may have been encouraged more than the ones attending to the public schools due to their families' higher income and educational backgrounds. In a study done by Ozkafacı [33] argued that the families having higher socio-economic and educational levels are more interested with their children and can satisfy their children's social needs better than others. Eskicumali and Eroglu [34] mentioned that the families' socio-economic levels, their attitudes and tendencies towards their children, their educational backgrounds and other external factors have impact on the $4^{\text {th }}$ and $5^{\text {th }}$ grade students' skills such as problem solving skills. Consequently, the higher socio-economic levels of the families of the students attending to private schools, their attitudes and active participation to the education may have had a positive impact on the students' motivations. Another explanation for this finding may be the fact that private schools organize field excursions in science lessons and weekend activities and provide enriched learning environments, so these activities may have increased the students' motivation level

When the related literature is analyzed, it can be seen that the number of the studies conducted on private schools are limited. The differentiated classroom activities can be organized easily in these schools than the public schools affiliated to MoNE. From the findings of this present study, it can be said that the students attending to private schools are able to plan their learning processes, control and regulate, whereby increasing their motivations. After the Grid Model implementation, it can be said that the Grid Model maintains the high levels of motivation towards the self-regulation when we consider that the students attending to the private schools have high scores as to the related dimensions.

\section{Results and Recommendations}

In this present study, the students with a different intelligence and learning levels have been provided with differentiated activities. It was found that the differentiated curriculum according to the Grid Model have increased the motivation of the students attending the public schools towards the self-regulation. According to the findings of the study, it can be said that the Grid Model has a positive impact on increasing the motivations of the students with lower socio-economic levels towards the self-regulation.

According to the findings of the study, it was found that the Grid Model affects the internal goal orientations of both the students attending to private schools and those in public schools in a positive direction. On the other hand, it doesn't have any effect on the students' external goal orientations. When this circumstance is taken into consideration, it can be concluded that the Grid Model significantly contributes to the internal motivation levels to the self-regulation skills of the students.

In other findings of the study, it was found out that the Grid Model has a positive impact on the self-efficacy and task value perceptions of the students attending to public schools. From this finding, it can be concluded that the Grid Model has a positive impact on the attitudes and self-efficacy perceptions of the students attending to public schools towards science tasks, whereby increasing the meaningfulness of the science tasks.

In the present study, there wasn't any change after the Grid Model implementations in the sub-dimension of learning control belief. It can be concluded that students from both private and public schools didn't believe in themselves to be able to make a difference on learning outcomes within the scope of the Grid Model. It is thought that this situation didn't result from the features of the Grid Model. Rather, it may have arisen from the teacher implementation processes of the model. From the findings of the study, it can be said that teachers must give the necessary feedback to the students in order to carry out the Grid Model. The students learning control beliefs must be 
developed so as to increase their motivations for self-regulation. The explanation for this finding may be analyzed in detail via detailed interviews with teachers.

It was found out that the Grid Model didn't have any effect on increasing the motivations for self-regulation skills of the students with high socio-economic levels but their motivations scores didn't decrease, either. From this situation, it can be concluded that the Grid Model maintains the high motivations of the students with high socio-economic level towards the self-regulation. As a result, it was found out that the Grid Model is successful in increasing the motivations of the students with low socio-economic level for self-regulation and maintains the high motivations of the students with high socio-economic level towards the self-regulation.

It can be said that the Grid Model contributes to the development of the motivations of the students towards the self-regulation. At this point, it can be said that teachers have implemented the model successfully. However, it was observed that some teachers implementing the model had difficulty in evaluating the students' outcomes and giving necessary feedback. A detailed guidance or orientation may be provided the teachers implementing the model in order to guide and evaluate the students' tasks appropriately.

There may be different variables affecting the implementation of the model even though it was tried to analyze the effects of the Grid Model in developing motivations of the students towards to self-regulation. It is difficult to generalize the findings of this present study just according to the data obtained in a city. In order to eliminate this limitation, a full experimental study can be conducted by increasing the number of the participants in the population.

The findings found in this present study are limited with the data obtained from motivation dimension of MSLQ. For the future research, the self-regulation can be studied sweepingly, including the data obtained related to behavioral, contextual and cognitive dimensions of the Grid Model.

This present study was structured according to Pintrich's self-regulation learning theory [21]. For the future research, the effects of the Grid Model can be analyzed by considering different self-regulation learning theories. The results can be compared by using different self-regulations scales.

\section{Glossary}

The Grid Model - A Differentiated Science Curriculum according to the Features of Kaplans' Depth and Complexity Prompts.

Primary School Students - Gifted and Non-gifted Students Studying at $4^{\text {th }}$ Grade and Recognized by the Guidance and Research Center.
Motivation for Self-Regulation - The Motivation Dimension of Pintrich in Self-Regulation Theory.

\section{REFERENCES}

[1] Jonassen, D. H. \& Grabowski, B. L. (1993). Handbook of individual differences learning and instruction. New Jersey: Lawrence Erlbaum Associates.

[2] Aktepe, V. (2005). Eğitimde bireyi tanımanın önemi, Gazi Üniversitesi Kırşehir Eğitim Fakültesi Dergisi, 6(2), 15-24.

[3] Candan, Ç., Tuncer, B. \& Karataş, H. (2015). Program değerlendirme sürecinde bireysel farklilıkların önemi, Eğitim ve Öğretim Araştırmaları Dergisi, 4(3), 307-312.

[4] Turgut, Ü., Salar, R., Aksakallı, A. \& Gürbüz, F. (2016). Bireysel farklıkların ögretim sürecine yansımasına dair ögretmen görüşlerinin incelenmesi: nitel bir araştırma, Bayburt Ĕgitim Fakültesi Dergisi, 11(2), 432-444.

[5] Sünbül, A. M. (2004). Öğretimde planlama ve değerlendirme dersinde ögrenme stillerine dayalı ögretim uygulamasının öğrenci erişilerine ve öğrenilenlerin kalıcılığına etkisi, Selçuk Üniversitesi Eğitim Fakültesi Dergisi, 16(18), 367-380.

[6] Evin-Gencel, İ. (2006). Öğrenme stilleri, deneyimsel ögrenme kuramına dayalı eğitim, tutum ve sosyal bilgiler program hedeflerine erişi düzeyi (Unpublished doctoral thesis), Dokuz Eylül Üniversitesi, İzmir, Turkey.

[7] Özdemir, N. (2015). An experimental study related to application of the kolb's learning cycle in geography lectures, Hacettepe Üniversitesi Journal of Education, 30(2), 81-98.

[8] Olszewski-Kubilius, P. \& Thomson, D. (2015). Talent development as a framework for gifted education, Gifted Child Today, 38(1), 49-59.

[9] Renzulli, J. S. (2005). Applying gifted education pedagogy to total talent development for all students, Theory into Practices, 44(2), 80-89.

[10] Renzulli, J. S. (2014). The schoolwide enrichment model: a comprehensive plan for the development of talents and giftedness, Revista Educação Especial, 27(50), 539-562.

[11] Renzulli, J. S., \& Reis, S. M. (1997). The schoolwide enrichment model: A guide for developing defensible programs for the gifted and talented. Mansfield Center, CT: Creative Learning Press.

[12] Renzulli, J. S. (2000). The identification and development of giftedness as a paradigm for school reform, Journal of Science Education and Technology, 9(2), 95-114.

[13] Manzone, J. A. (2013). The elements of a differentiated curriculum for gifted students: transfer and application across the disciplines. (Unpublished doctoral thesis) University of Southern California, Los Angeles, U.S.

[14] Grubb, R. C. (2011). The relationship between the implementation of a differentiated curriculum and the development of intellectualism. (Unpublished doctoral 
thesis), University of Southern California, Los Angeles, U.S.

[15] Dodds, K. M. (2010). Effects of the prompts of depth and complexity on gifted and non-gifted students. (Unpublished doctoral thesis). University of Southern California, Los Angeles, U.S.

[16] Kaplan, S. N. (1986). The Grid: A model to construct differentiated curriculum for the gifted. In J. S. Renzulli (Ed.) Systems and Models for Developing Programs for the Gifted and Talented (pp. 180-193). Mansfield Center, CT: Creative Learning Press.

[17] Hunt, L. \& Yoshida-Ehrmann, E. (2016), Linking schools of thought to schools of practice, Gifted Child Today, 39(3), 164- 172

[18] McIntosh, J. S. (2015). The depth and complexity program evaluation tool: a new method for conducting internal evaluations of gifted education programs. (Unpublished doctoral thesis). Purdue University, West Lafayette, Indiana.

[19] Park, M. A. (2008). Factors affecting the transfer of differentiated curriculum from professional development into classroom practice. (Unpublished doctoral thesis), University Southern California, Los Angeles, US.

[20] Campbell, D. T., \& Stanley, J. C. (1963). Experimental and quasi-experimental designs for research on teaching. In N. L. Gage (Ed.), Handbook of research on teaching (pp. 171246). Chicago, IL: Rand McNally.

[21] Pintrich P. R. \& De Groot, E.V. (1990). Motivational and Self-Regulated Learning Components of Classroom Academic Performance. Journal of Educational Psychology, 83(1), 33-40.

[22] Karadeniz, Ş., Büyüköztürk, Ş., Akgün, Ö. E., Çakmak, E. K. $\&$ Demirel, F. (2008). The Turkish adaptation study of motivated strategies for learning questionnaire (MSLQ) for 12-18 year old children: results of confirmatory factor analysis, The Turkish Online Journal of Educational Technology (TOJET), 7(4), 108-117.

[23] Ministry of National Edication (MoNE) (2013). Science cource educational and instructional program.

[24] Gentry, M. \& Mann, R. L. (2008). A comprehensive, research-based plan for raising student achievement \& improving teacher practices (Ed. Rachel A. Knox) Total
School Cluster Grouping \& Differentiation Creative Learnıng Press, 130-136.

[25] Büyüköztürk, Ş., Çoklu, Ö. \& Köklü, N. (2013). Sosyal bilimler için istatistik (13 ${ }^{\text {th }}$ Edition), Ankara: Pegem Akademi.

[26] Akdeniz, A. R. (2011). Problem çözme, bilimsel süreç ve proje yönteminin fen eğitiminde kullanımı, (Ed. Çepni, S.) Kuramdan uygulamaya fen ve teknoloji öğretimi, Pegem Akademi ( $9^{\text {th }}$ Edition $)$, Ankara.

[27] Ryan, R.M. \& Deci, E.L. (2000). Intrinsic and extrinsic motivations: classic definitions and new directions, Contemporary Educational Psychology, 25, 54-67.

[28] Yamaç, A. (2011). İlköğretim beşinci sinıf ögrencilerinin öz-düzenleyici ögrenme stratejileri ile matematiğe yönelik tutum ve başarları arasindaki iliskilerin incelenmesi. (Unpublished master thesis), Afyon Kocatepe University, Afyon, Turkey.

[29] Schunk, D. H. \& Zimmerman, Barry J. (1998). Self-regulated learning from teaching to self-reflective practice. New York: Guilford Press.

[30] Mulyadi, S., Heru Basukib, A.M. \& Rahardjo, W. (2016) Student's tutorial system perception, academic self-efficacy, and creativity effects on self-regulated learning, Procedia Social and Behavioral Sciences, 217, 598 -602.

[31] Pintrich, P. R. (2004), A conceptual framework for assessing motivation and self-regulated learning in college students, Educational Psychology Review, 16 (4), 385-407.

[32] Çalıkoğlu, B. S. (2014). Üstün zekâlı ve yetenekli öğrencilerde derinlik ve karmaşıklığa göre farklılaştırılmış fen öğretiminin başarı, bilimsel süreç becerileri ve tutuma etkisi. (Unpublished doctoral thesis), Istanbul University, Istanbul, Turkey.

[33] Özkafac1, A. A. (2012). Annenin çocuk yetiștirme tutumu ile çocuğun sosyal beceri düzeyi arasındaki ilişkinin incelenmesi. (Unpublished master thesis), Istanbul Ar-El University, Istanbul, Turkey.

[34] Eskicumal1, A. \& Eroğlu, E. (2001). Ailenin sosyo ekonomik ve eğitim düzeyleri ile çocukların problem çözme yetenekleri arasındaki ilişki. Sakarya Üniversitesi Eğitim Fakültesi Dergisi, 1, 160-182. 